\title{
PENGARUH PENGGUNAAN MODEL KOOPERATIF TIPE TEAMS GAMES TOURNAMENT TERHADAP HASIL BELAJAR SISWA PADA PEMBELAJARAN PKN DI KELAS IV SDN 33 RAWANG BARAT KOTA PADANG
}

\author{
Oleh \\ Monika $^{1)}$, Dra. Tin Indrawati, M.Pd ${ }^{2)}$, Dra. Reinita, M.Pd ${ }^{3)}$ \\ ${ }^{1)}$ Mahasiswa, Universitas Negeri Padang, Indonesia \\ ${ }^{2}$ Pembimbing 1, Univesitas Negei Padang, Indonesia \\ ${ }^{3)}$ Pembimbing 2, Univesitas Negei Padang, Indonesia \\ ${ }^{1)}$ monika.cimon06@gmail.com, ${ }^{2)}$ indrawati tin@yahoo.com, \\ ${ }^{3)}$ reinita_reinita@yahoo.com
}

\begin{abstract}
Abstrak
Penelitian ini dilatarbelakangi oleh kenyataan yang ditemukan di lapangan bahwa hasil belajar siswa dalam mata pelajaran PKn masih kurang memuaskan serta pembelajaran yang masih didominasi oleh guru sebagai sumber informasi. Untuk mengatasinya dilakukan tindakan dengan menggunakan model pembelajaran inovatif yang dapat diterapkan pada mata pelajaran PKn yang salah satunya yaitu model pembelajaran kooperatif tipe Team Games Tournament. Penelitian ini bertujuan untuk mengetahui pengaruh penggunaan model pembelajaran kooperatif tipe Team Games Tournament. terhadap hasil belajar PKn siswa kelas IV SDN 33 Rawang Barat Kota Padang. Jenis penelitian yang dilakukan adalah quasi eksperiment. Instrrumen penelitian yang digunakan adalah tes tertulis. Berdasarkan hasil penelitian, diperoleh nilai rata-rata kelas eksperimen adalah 64,48 dan nilai rata-rata kelas kontrol adalah 54,83. sehingga dapat disimpulkan bahwa terdapat pengaruh penggunaan model pembelajaran kooperatif tipe Team Games Tournament. terhadap hasil belajar PKn siswa kelas IV SDN 33 Rawang Barat Kota Padang.
\end{abstract}

Kata Kunci: Model pembelajaran Kooperatif Tipe Teams Games Tournament, hasil belajar

\begin{abstract}
This research was supported by the problems found in the field that the students' learning outcomes in Civic Education were less satisfactory and the learning process was still dominated by the teachers as a source of information. The cooperative model of Teams Games Tournament is one of the alternative models that can be applied in Civic Education class to overcome the problems. Thus, this research was undertaken as an attempt to assess the effect of cooperative learning model of Teams Games Tournament on the fourth grade students' learning outcomes in Civic Education at SDN 33 Rawang Barat Padang. This research adopted a quasi-experimental research design with quantitative approach. The instrument for data collection was the written test. The result of the research revealed that the average score of the experimental class which applied cooperative learning model of teams games tournament compared to the control class showed better achievement. The result obtained from the data showed that there is more positive effect of using Cooperative Learning Model of Teams Games Tournament toward fourth grade students' learning outcomes in Civic Education at SDN 33 Rawang Barat Padang.
\end{abstract}

Key words: Cooperative Model Teams Games Tournament, Learning outcomes 


\section{PENDAHULUAN}

\section{Model Teams Games Tournament} dapat dijadikan sebagai salah satu metode pembelajaran yang dapat digunakan dalam proses pembelajaran. Berdasarkan Asma (2008: 61) Model TGT adalah suatu model pembelajaran yang didahului dengan penyajian materi pembelajaran oleh guru dan diakhiri dengan memberikan sejumlah pertanyaan kepada siswa, setelah itu, siswa pindah kekelompok masing-masing untuk mendiskusikan dan menyelesaikan pertanyaan-pertanyaan atau masalahmasalah yang diberikan oleh guru. Sebagai ganti dari tes tertulis, setiap siswa akan bertemu seminggu sekali pada meja turnament dengan dua rekan dari kelompok lain untuk membandingkan kemampuan kelompoknya dengan kelompok lain.

Pembelajaran PKn sangat berperan penting dalam membentuk manusia yang berbudi luhur, bertanggung jawab, ikut berpartisipasi dalam kegiatan bermasyarakat. Siswa dapat belajar mengenai berbagai hal yang berkaitan dengan sikap menghormati dan tengang rasa melalui mata pelajaran PKn. Pendidikan Kewarganegaraan (PKn) merupakan mata pelajaran yang dipelajari siswa di Sekolah Dasar (SD) yang menekankan pada pembentukan sikap agar menjadi warga negara yang baik, dan melaksanakan hak dan kewajiban sebagai warga negara. Depdiknas (2006: 2) mengemukakan bahwa "Mata pelajaran PKn merupakan mata pelajaran yang memfokuskan pada pembentukan warga negara yang memahami dan mampu melaksanakan hak dan kewajibannya untuk menjadi warga negara Indonesia yang cerdas, terampil, dan berkarakter sesuai dengan yang diamanatkan oleh pancasila dan UUD 1945." Selanjutnya Erwin (2011: 3) menjelaskan bahwa "Pendidikan Kewarganegaraan di Indonesia merupakan pendidikan kebangsaan dan kewarganegaraan yang berhadapan dengan keberadaan Negara Kesatuan Republik Indonesia, demokrasi, HAM, dan cita-cita untuk mewujudkan masyarakat madani Indonesia dengan menggunakan Filsafat Pancasila sebagai pisau analisisnya.”

Tujuan dari Mata Pelajaran PKn untuk jenjang pendidikan SD/MI berdasarkan Depdiknas (2006: 271) diantaranya yaitu berkembang secara positif dan demokratis untuk membentuk diri berdasarkan karakter masyarakat indonesia agar dapat hidup bersama dengan bangsabangsa lainnya dalam persatuan percaturan dunia secara langsung atau tidak langsung dengan memanfaatkan teknologi, informasi dan komunikasi.

Berdasarkan pengamatan yang dilakukan di SDN 33 Rawang Barat, peneliti menemukan permasalahan bahwa hasil belajar siswa pada mata pelajaran PKn masih kurang memuaskan. Hal ini di 
sebabkan oleh kesulitan siswa dalam memahami materi pembelajaran PKn. Permasalahan tersebut juga di sebabkan oleh tidak bervariasinya model pembelajaran yang di gunakan. Guru sering menggunakan metode ceramah sehingga siswa akan mudah merasa bosan karena tidak di libatkan untuk aktif dalam proses pembelajaran. Hal ini berdampak pada hasil belajar PKn siswa yang kurang memuaskan.

Dengan pola pembelajaran seperti ini, akan menyebabkan pembelajaran yang monoton, sehingga siswa tidak memiliki motivasi untuk belajar dan aktivitasnya akan berkurang.Salah satu cara untuk meningkatkan hasil belajar, kreatifitas dan aktivitas belajar siswa yaitu dengan menggunakan Model Kooperatif Tipe Teams Games Tournament. Model Kooperatif Tipe Teams Games Tournament dapat dijadikan sebagai salah satu variasi model yang dapat digunakan untuk mengajarkan siswa SD pada pembelajaran PKn.

Berdasarkan permasalahan diatas, peneliti tertarik untuk membuat rencana penelitian yang diberi judul "Pengaruh Penggunaan Model Kooperatif Tipe Teams Games Tournament terhadap Hasil Belajar Siswa dalam Pembelajaran PKn di Kelas IV SDN 33 Rawang Barat Kota Padang”.

Tujuan penelitian ini adalah Untuk Mengetahui terdapat tidaknya pengaruh Model Kooperatif tipe Teams Games
Tournament terhadap Hasil Belajar Siswa dalam Pembelajaran PKn di Kelas IV SDN 33 Rawang Barat Kota Padang.

\section{METODOLOGI}

Dalam penelitian ini, digunakan pendekatan kuantitatif dalam jenis penelitian eksperimen. Menurut Sugiyono (2011:107) penelitian eksperimen sebagai metode penelitian yang digunakan untuk mencari pengaruh perlakuan tertentu terhadap yang lain dalam kondisi yang terkendalikan. Penelitian eksperimen yang akan dilakukan yaitu Quasi Eksperiment design (eksperimen semu). Desain Penelitian yang digunakan adalah Pre-test and post-test group design. Desain ini dibedakan dengan adanya pretest sebelum perlakuan diberikan. Penelitian ini dilaksanakan di SDn 33 Rawang Barat Kota Padang. Populasi dalam penelitian yang akan dilakukan adalah seluruh siswa kelas IV SDn 33 Rawang Barat Kota Padang tahun pelajaran 2017/2018. Penarikan sampel pada penelitian ini dilakukan dengan Probality sampling yang meliputi simple random sampling.

Instrumen yang digunakan dalam penelitian ini adalah soal tes hasil belajar. Soal tes diuji coba terlebih dahulu yang berbentuk soal pilihan ganda berjumlah 40 butir. Tes dilihat validasi, daya beda, indeks kesukaran dan reliabelitas soal, sehingga didapatkan tes hasil belajar PKn soal pilihan ganda berjumlah 20 butir yang 
diberikan kepada kedua kelas sampel yaitu pretest dan posttest.

Dalam penelitian ini terdapat dua variabel yaitu varibel bebas dan variabel terikat. Variabel bebas adalah variabel yang mempengaruhi atau yang menjadi sebab perubahan atau timbulnya varibel terikat. Variabel bebas pada penelitian ini adalah Model Teams Games Tournament. Sedangkan variabel terikat adalah variabel yang dipengaruhi atau yang menjadi akibat adanya variabel bebas. Variabel terikat pada penelitian ini adalah hasil belajar. Penelitian ini menggunakan dua kelas sampel yaitu kelas eksperimen dan kelas kontrol. Kelas eksperimen dengan menggunakan Model Teams Games Tournament. sedangkan kelas kontrol tidak menggunakan Model

\section{Teams Games Tournament.}

Posttest diberikan pada kedua kelas sampel untuk melihat hasil belajar PKn siswa setelah diberikan perlakuan, seberapa jauh pengaruh Model Teams Games Tournament. terhadap hasil belajar PKn siswa. Teknik analisa data menggunakan uji $\mathrm{t}$ ( $\mathrm{t}$-test) dengan taraf $\alpha=0,05$. Rumus uji- $\mathrm{t}$ yang digunakan Menurut Lestari dan Yudhanegara (2015: 280) yaitu sebagai berikut:

$\mathrm{t}_{0}=\frac{Y_{1}-Y_{2}}{S_{1}}$, dimana

$$
\begin{aligned}
& \mathrm{S}_{\mathrm{e}} \quad=\quad \sqrt{\frac{\left(n_{1}+n_{2}\right)\left(\Sigma y_{1}^{2}+\Sigma y_{2}^{2}\right)}{\left(n_{1}\right)\left(n_{2}\right)\left(n_{1}+n_{2}-2\right)}}= \\
& \sqrt{\frac{(d b+2)\left(\left(\Sigma y_{1}^{2}+\Sigma y_{2}^{2}\right)\right.}{\left(n_{1}\right)\left(n_{2}\right)(d b)}}
\end{aligned}
$$$$
\Sigma \mathrm{y}_{1}{ }^{2}=\Sigma \mathrm{Y}_{1}{ }^{2}-\frac{\left(\Sigma Y_{1}\right)^{2}}{n_{1}} \text { dan } \Sigma \mathrm{y}_{2}{ }^{2}=
$$$$
\Sigma Y_{2}^{2}-\frac{\left(\Sigma Y_{2}\right)^{2}}{n_{2}}
$$

Jika $\quad \mathrm{t}_{0} \leq \mathrm{t}_{\text {tabelmakahipotesisnihil }}\left(\mathrm{H}_{0}\right)$ diterima

Jika $\mathrm{t}_{0}>\mathrm{t}_{\text {tabel }}$ maka hipotesis nihil $\left(\mathrm{H}_{0}\right)$ ditolak

$\mathrm{H}_{1}$ : Terdapat Pengaruh yang signifikan dalam penerapan model Teams Games Tournament terhadap hasil belajar dalam pembelajaran PKn di kelas IV SDN 33 Rawang Barat.

$\mathrm{H}_{0}$ : Tidak terdapat pengaruh yang signifikan dalam penerapan model Teams Games Tournament terhadap hasil belajar dalam pembelajaran PKn di kelas IV SDN 33 Rawang Barat.

\section{HASIL PENELITIAN DAN PEMBAHASAN}

\section{Deskripsi Data}

a. Data pretest kedua kelas sampel

Pretest dilaksanakan di SD 33 Rawang Barat dengan jumlah 62 orang. Tabel 1. Data Hasil Pretest Kedua Kelas

\begin{tabular}{|c|c|c|}
\hline \multirow{2}{*}{ Variabel } & \multicolumn{2}{|c|}{ Pretest } \\
\cline { 2 - 3 } & $\begin{array}{c}\text { Kelas } \\
\text { eksperimen }\end{array}$ & $\begin{array}{c}\text { Kelas } \\
\text { kontrol }\end{array}$ \\
\hline $\mathrm{N}$ & 33 & 29 \\
\hline $\begin{array}{c}\text { Nilai } \\
\text { tertinggi }\end{array}$ & 80 & 85 \\
\hline $\begin{array}{c}\text { Nilai } \\
\text { terendah }\end{array}$ & 20 & 25 \\
\hline Mean & 54,55 & 53,62 \\
\hline SD & 14,86 & 17,57 \\
\hline
\end{tabular}




\begin{tabular}{|l|l|l|}
\hline $\mathrm{SD}^{2}$ & 220,81 & 308,70 \\
\hline
\end{tabular}

Dari nilai kelas eksperimen diperoleh rata-rata nilai sebesar 54,55, standar deviasi 14,86 dan nilai varians 220,81 . Sedangkan kelas kontrol dengan jumlah siswa 29 orang memperoleh nilai tertinggi 85 dan nilai terendah 25. Dari nilai kelas kontrol diperoleh rata-rata nilai sebesar 53,62, standar deviasi 17,57. Dan nilai varians 308,70 . Untuk lebih jelasnya dapat dilihat pada grafik berikut:

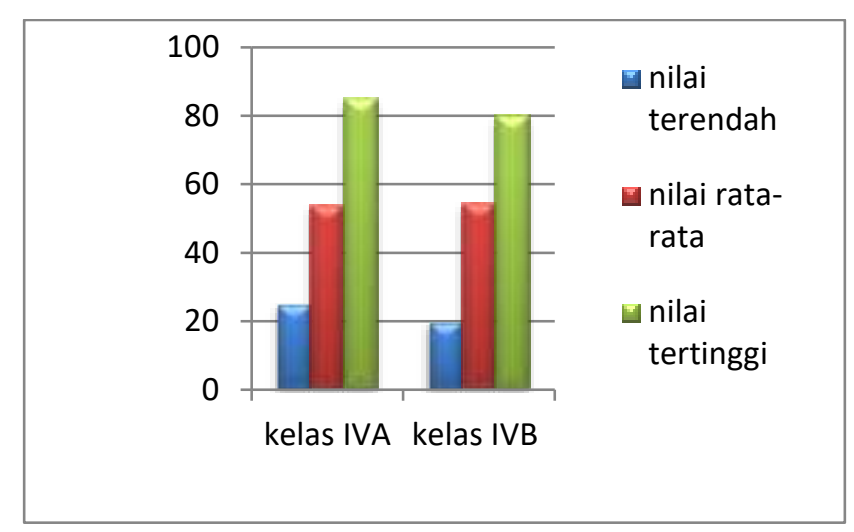

Grafik 1. Perbandingan hasil pretest kelas eksperimen dan kelas kontrol

b. Data posttest kedua kelas sampel

Posttest dilaksanakan di SDn 33

Rawang Barat dengan jumlah 29 orang.

Tabel 2. Data Hasil Posttest Kedua Kelas

\begin{tabular}{|c|c|c|}
\hline \multirow{2}{*}{ Variabel } & \multicolumn{2}{|c|}{ Pos-test } \\
\cline { 2 - 3 } & $\begin{array}{c}\text { Kelas } \\
\text { Eksperimen }\end{array}$ & $\begin{array}{c}\text { Kelas } \\
\text { Kontrol }\end{array}$ \\
\hline N & 29 & 29 \\
\hline $\begin{array}{c}\text { Nilai } \\
\text { Tertinggi }\end{array}$ & 90 & 90 \\
\hline $\begin{array}{c}\text { Nilai } \\
\text { Terendah }\end{array}$ & 25 & 20 \\
\hline Mean & 64,48 & 54,83 \\
\hline SD & 18,72 & 17,80 \\
\hline
\end{tabular}

\begin{tabular}{|c|c|c|}
\hline $\mathrm{SD}^{2}$ & 350,616 & 316,934 \\
\hline
\end{tabular}

Dari nilai kelas eksperimen diperoleh rata-rata nilai sebesar 64,48, standar deviasi 18,72. Sedangkan kelas kontrol dengan jumlah siswa 29 orang memperoleh nilai tertinggi 90 dan nilai terendah 20. Dari nilai kelas kontrol diperoleh rata-rata nilai sebesar 54,83, standar deviasi 17,80. Untuk lebih jelasnya dapat dilihat pada grafik berikut:

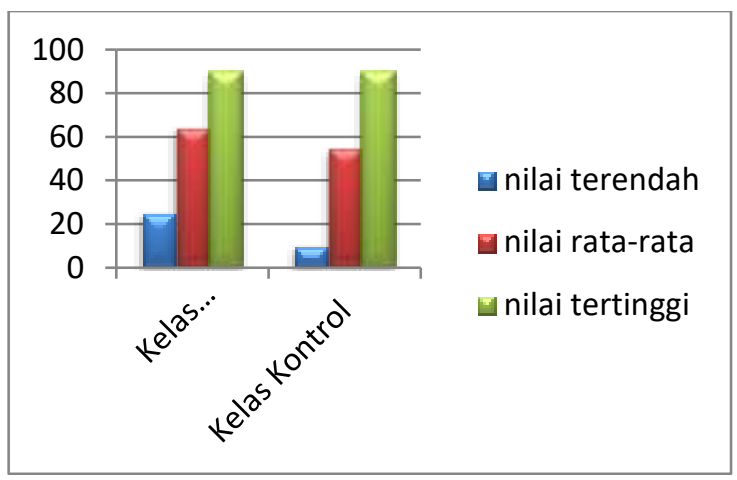

Grafik 2. Perbandingan hasil posttest kelas eksperimen dan kelas kontrol

\section{Analisa Data}

Analisis data dilakukan untuk menarik kesimpulan tentang data hasil belajar. Untuk mengetahui apakah terdapat pengaruh yang positif untuk nilai kedua kelompok maka dilakukan uji hipotesis. Sebelum uji hipotesis dilakukan, terlebih dahulu dilakukan uji normalitas dan uji homogenitas terhadap sampel.

1) Uji Normalitas

Data yang digunakan untuk uji normalitas adalah nilai tes akhir yang digunakan pada kelas eksperimen dan kelas kontrol diakhir pertemuan. Pada uji 
normalitas ini digunakan uji KolmogorovSmirnov seperti yang dikemukakan pada teknik analisis data. Berdasarkan uji normalitas kelas eksperimen dan kelas kontrol diperoleh $\mathrm{D}_{0}$ dan $\mathrm{D}_{\text {tabel}}$, pada taraf nyata 0,05 untuk $n>29$ pada tabel.

Tabel 3. Hasil Perhitungan Pengujian Kolmogorov-Smirnov Kelompok Eksperimen dan Kelompok Kontrol

\begin{tabular}{|c|c|c|c|c|c|c|}
\hline $\begin{array}{l}\mathbf{N} \\
\mathbf{0}\end{array}$ & $\begin{array}{c}\text { Kela } \\
\text { s }\end{array}$ & $\mathbf{N}$ & $\mathbf{A}$ & $\mathbf{D}_{0}$ & $\mathbf{D}_{\text {tabel }}$ & Ket \\
\hline 1. & $\begin{array}{c}\text { Eksp } \\
\text { erim } \\
\text { en }\end{array}$ & $\begin{array}{l}2 \\
9\end{array}$ & $\begin{array}{c}0,0 \\
5\end{array}$ & $\begin{array}{c}0,03 \\
5578\end{array}$ & 0,24 & $\begin{array}{l}\text { Nor } \\
\text { mal }\end{array}$ \\
\hline 2. & $\begin{array}{c}\text { Kont } \\
\text { rol }\end{array}$ & $\begin{array}{l}2 \\
9\end{array}$ & $\begin{array}{c}0,0 \\
5\end{array}$ & $\begin{array}{c}0,09 \\
0813\end{array}$ & 0,24 & $\begin{array}{l}\text { Nor } \\
\text { mal }\end{array}$ \\
\hline
\end{tabular}

2) Uji Homogenitas

Pengujian persyaratan yang kedua adalah pengujian homogenitas dengan menggunakan uji Bartlett. Pengujian ini bertujuan untuk mengetahui apakah data berasal dari kelompok yang homogen antara kelas eksperimen dan kelas kontrol. Hasil perhitungan uji homogenitas dapat dilihat pada tabel:

Tabel 4. Hasil Uji Homogenitas Kelas Eksperimen dan Kelas Kontrol

\begin{tabular}{|c|c|c|c|c|}
\hline Kelas & $\mathbf{A}$ & $\mathbf{b}_{\text {hitun }}$ & $\mathbf{b}_{\text {tabel }}$ & $\begin{array}{c}\text { Keteran } \\
\text { gan }\end{array}$ \\
\cline { 1 - 4 } Eksperim & 0,0 & 2,00 & 0,932 & Homoge \\
en & 5 & 0 & 7 & $\mathrm{n}$ \\
\cline { 1 - 1 } Kontrol & & & & \\
\hline
\end{tabular}

3) UjiHipotesis

Setelah uji normalitas dan uji homogenitas dilakukan, kemudian dilanjutkan dengan pengujian t-tes untuk mengetahui apakah terdapat pengaruh yang positif dari nilai kedua kelompok. Apabila $t_{\text {hitung }}>t_{\text {tabel }}$ berarti terdapat pengaruh yang positif antara kedua kelompok. Berikut ini digambarkan pengolahan data dengan $t_{\text {test }}$ pada tabel:

Tabel 5. Data Hasil Perhitungan Analisis Nilai Kelas Eksperimen dan Kelas Kontrol

\begin{tabular}{|c|c|c|}
\hline Aspek & $\begin{array}{c}\text { Kelas } \\
\text { Eksperimen }\end{array}$ & $\begin{array}{c}\text { Kelas } \\
\text { Kontrol }\end{array}$ \\
\hline $\mathrm{N}$ & 29 & 29 \\
\hline$X$ & 64,48 & 54,83 \\
\hline $\mathrm{SD}^{2}$ & 227,4852 & 218,2358 \\
\hline
\end{tabular}

$$
t_{\text {hitung }}=\frac{\overline{x_{1}-\bar{x}_{2}}}{\mathrm{~s} \text { gabungan } \sqrt{\frac{n_{1+n_{2}}}{n_{1} \cdot n_{2}}}}
$$

$$
S_{\text {gabungan }}=\sqrt{\frac{\left(\mathrm{n}_{1}-1\right) \mathrm{S}_{1}^{2}+\left(\mathrm{n}_{2}-1\right) \mathrm{S}_{2}^{2}}{\mathrm{n}_{1}+\mathrm{n}_{2}-2}}
$$

S gabungan

$$
\sqrt{\frac{(29-1) \times(227,4852)+(29-1) \times(218,2358)}{29+29-2}}
$$

$=$

$\sqrt{\frac{(28) \times(227,4852)+(28) \times(218,2358)}{56}}$

$$
\begin{aligned}
& =\sqrt{\frac{(6369,585)+(6110,602)}{56}} \\
& =\sqrt{\frac{12480,187}{56}} \\
& =\sqrt{222,8605} \\
& =14,93
\end{aligned}
$$




$$
\begin{aligned}
& \mathrm{t}_{\text {hitung }}=\frac{\mathrm{x}_{1}-\mathrm{X}_{2}}{\mathrm{~s}} \\
& =\frac{64,48-54,83}{14,93 \sqrt{\frac{29+29}{29 \times 29}}} \\
& =\frac{64,48-54,83}{14,93 \sqrt{0,0689}} \\
& =\frac{9,65}{14,93 \times 0,262} \\
& =\frac{9,65}{3,911} \\
& =2,467 \\
& \mathrm{t}_{\text {tabel }}=\mathrm{t}_{(\alpha, \mathrm{dk})}=\mathrm{t}_{(0,05,56)=2,003}
\end{aligned}
$$

Untuk mengkaji hipotesis digunakan t-test. Dari hasil uji hipotesis dengan menggunakan t-test diperoleh hasil sebagai berikut:

Tabel 6. Hasil Pengujian dengan t-test

\begin{tabular}{|l|l|l|l|l|}
\hline No & $\begin{array}{c}\text { Kelompok } \\
\text { /Hasil }\end{array}$ & $\begin{array}{l}\text { Nilai } \\
\text { Rata- } \\
\text { rata } \\
\text { kelas }\end{array}$ & $\mathbf{t}_{\text {hitung }}$ & $\mathbf{t}_{\text {tabel }}$ \\
\cline { 1 - 3 } 1. & Eksperimen & 64,48 & $\mathbf{2 , 4 6 7}$ & $\mathbf{2 , 0 0 3}$ \\
\hline 2. & Kontrol & 54,83 & & \\
\hline
\end{tabular}

Dengan demikian, $t_{\text {hitung }}>t_{\text {tabel, }}$ yaitu $2,467>2,003$. Maka dapat disimpulkan bahwa hasil belajar siswa yang mengikuti pembelajaran dengan model Teams Games Tournament lebih tinggi dari hasil belajar tidak menggunakan model ini, dan terdapat pengaruh yang positif dari hasil belajar siswa antara kelas eksperimen yang menggunakan model Teams Games
Tournament dibandingkan dengan kelas kontrol yang menggunakan pembelajaran dengan metode konvensional (ceramah dan tanya jawab).

Berdasarkan hasil pengolahan data dengan menggunakan uji $t$, bahwa $t_{\text {hitung }}$ sebesar 2,467 dan $t_{\text {tabel }}$ sebesar2,003, dengan $\mathrm{t}_{\text {hitung }}$ lebih besar dari $\mathrm{t}_{\text {tabel }}(2,467>2,003)$, yang berarti terdapat perbedaan yang signifikan terhadap hasil belajar siswa yang menggunakan model Teams Games Tournament dengan pembelajaran yang tidak menggunakan model Teams Games Tournament.

Hasil penelitian berdasarkan tes akhir yang diberikan kepada siswa kelas IV SDn 33 Rawang Barat Kota Padang kelas eksperimen 29 orang siswa diperoleh nilai rata-rata 64,48. Sedangkan kelas kontrol dari 29 orang siswa diperoleh nilai rata-rata 54,83 .

Berdasarkan analisis data, dapat dilihat bahwa terdapat perbedaan yang signifikan antara kelas eksperimen yang menggunakan model Teams Games Tournament dengan yang tidak menggunakan model Teams Games Tournament.Hal ini membuktikan tingginya tingkat pemahaman siswa terhadap materi yang disampaikan menggunakan model Teams Games Tournament .Ini dilihat dari nilai rata-rata siswa pada kedua kelas, dengan nilai rata-rata tertinggi yaitu pada kelas eksperimen. 
Analisis data yang dilakukan diperoleh $t_{\text {hitung }}=2,467$ dan $t_{\text {tabel }}=2,003$ yang berarti $t_{\text {hitung }}>t_{\text {tabel }}$. Ini membuktikan bahwa penggunaan model Teams Games Tournament pada mata pelajaran PKn di kelas IV SDn 33 Rawang Barat Kota Padang, mempunyai pengaruh yang signifikan pada taraf signifikan 0,05 terhadap hasil belajar siswa.

Dengan demikian apa yang dikatakan dalam hipotesis pada penelitian ini dapat diterima bahwa terdapat pengaruh yang siginifikan terhadap hasil belajar siswa yang mengikuti pembelajaran dengan menggunakan model Teams Games Tournament pada pembelajaran PKn di kelas IV SDn 33 Rawang Barat Kota Padang. Hal ini berarti terdapat pengaruh yang signifikan terhadap hasil belajar siswa kelas eksperimen yang menggunakan model Teams Games Tournament dibandingkan dengan yang tidak menggunakan model Teams Games Tournament .

Pada proses pembelajaran, hasil belajar siswa merupakan salah satu aspek dari hasil belajar. Pada hasil belajar mengenal struktur pemerintahan desa dan kecamatan Pada kelase ksperimen siswa diberi perlakuan dengan model Teams Games Tournament untuk mencapai empat indikator pembelajaran tersebut. Awalnya kedua kelas yaitu sama-sama diberi tes awal (pretest), tes awal atau pretes ini berguna untuk melihat keadaan awal dari kedua kelas. Selain itu juga untuk menentukan kelas eksperimen dan kelas kontrol. Setelah diperoleh hasil pretes dan diolah uji normalitas, homogenitas dan kesamaan rata-ratanya maka ditentukanlah kelas eksperimen dan kelas control dari kedua kelas tersebut. Kemudian pada pertemuan pertama di kelas eksperimen siswa diberikan pembelajaran dengan menggunakan model Teams Games Tournament. model Teams Games Tournament ini terdiri dari 4 langkah. Peneliti mengemukakan langkah-langkah menurut Slavin (2005: 166-180). Langkah yang pertama yaitu penyajian materi, langkah kedua yaitu belajar kelompok, langkah ketiga yaitu permainan, dan langkah keempat yaitu penghargaan kelompok.

Berdasarkan penelitian yang dilakukan dikelas eksperimen terlihat bahwa secara keseluruhan siswa mampu menyelesaikan tugas yang diberikan dan model Teams Games Tournament berpengaruh terhadap hasil belajar PKn siswa. Gambaran untuk hasil tes akhir dapat dilihat dari lembar jawaban tes akhir. Pada kelas kontrol pembelajaran tidak menggunakan model Teams Games Tournament (Model pembelajaran ceramah). Pada kelas control tidak semua siswa yang memperhatikan dengan baik, pada kelas kontrol siswa terlihat cendrung kurang aktif dalam belajar. Pada kelas 
control ini juga dilakukan sebanyak dua kali pertemuan sama halnya dengan kelas eksperimen. Setelah dua kali pertemuan selesai maka kelas control juga diberikan tes akhir.

Berdasarkan hasil penelitian membuktikan bahwa model Teams Games Tournament berpengaruh terhadap hasil belajar siswa yaitu dapat meningkatkan hasil belajar siswa.

\section{KESIMPULAN}

Berdasarkan hasil penelitian dan pembahasan bahwa model Teams Games Tournament berpengaruh terhadap hasil belajar siswa pada pembelajaran PKm di kelas IV SDn 33 Rawang Barat Kota Padang. Hasil penelitian menunjukkan nilai rata-rata yang diperoleh kelas eksperimen sebesar 64,48 sedangkan nilai rata-rata yang diperoleh kelas kontrol sebesar 54,83. Terdapat perbedaan yang mendominasi antara hasil belajar pada kelas eksperimen yang belajar dengan menggunakan model Teams Games Tournament dibandingkan dengan kelas kontrol yang tidak menggunakan model Teams Games Tournament. Dapat disimpulkan pembelajaran dengan menggunakan model Teams Games Tournament berpengaruh terhadap hasil belajar siswa pada pembelajaran PKn di kelas IV SDn 33 Rawang Barat Kota Padang.

\section{DAFTAR PUSTAKA}

Depdiknas. 2006. KurikulumTingkat Satuan Pendidikan Sekolah Dasar. Jakarta: Dirjen Pendidikan Tinggi. Lestari, K.E dan Yudhanegara, M.R. 2015. Penelitian Pendidikan Matematika. Bandung: PT Refika Aditama.

Muhammad Erwin. 2011. Pendidikan Kewarganegaraan Republik Indonesia. Bandung: Refika Aditama.

Nur asma. 2008. Model Pembelajaran Kooperatif. Padang: UNP Press.Nusa Media.

Robert E Slavin. 2005. Cooperative Learning Teori, Riset, Praktik. Bandung: Nusa Media.

Sugiyono. 2011. Metode Penelitian Pendidikan Pendekatan Kuantitatif, Kualitatif dan $R \& D$. Bandung: Alfabeta. 